STUDIA SPORTIVA 2013 / č. 3, s. 211-221

\title{
Do vody bez obav
}

\section{Into the water without fear}

\author{
Viktor Pacholík \\ Fakulta sportovních studií, Masarykova univerzita, Brno, \\ Česká republika
}

\section{Abstrakt:}

Přispěvek se zabývá problematikou vlivu Halliwickova konceptu plavecké výuky na subjektivní prožitky a psychické stavy osob s tělesným postižením. Pomocí programu plavecké výuky podle Halliwickova konceptu, který byl sestaven z 10 plaveckých lekcí, jsme v rámci př́padové studie sledovali psychickou odezvu jednotlivých lekcí i celého programu. Ziskané výsledky naznačuji pozitivni vliv plaveckého programu na zmirnění negativnich psychických stavů ve vztahu $k$ vodnímu prostředí, jako je úzkost, nepokoj a skličenost, a postupné zvyšováni míry psychické pohody, aktivity a činorodosti, pocitů sily a energie spojené s pozitivním očekáváním. Většina těchto změn se projevila jak v jednotlivých lekcích, tak z hlediska hodnocení změn v průběhu celého programu. Př́spěvek vznikl v rámci řešeni projektu OP VK CZ.1.07/2.4.00/17.0037 „,Rozvoj v oblasti pedagogicko-výzkumných aktivit na Katedře společenských věd ve sportu na FSpS MU“.

\section{Abstract:}

This list deals with the impact of the Halliwick Swimming Concept on subjective experience and psychical states of people with physical impairment. By means of the Halliwick Swimming Concept, that consisted of 10 swimming lessons, we observed the psychical response of the tested persons to individual lessons as well as to the whole programme within a frame of a case study.

The acquired data indicate a positive impact of the swimming programme in the field of elimination of negative psychical state in wa- 
ter environment such as anxiety, discomfort and despondency and gradual increase of psychical well-being, activity and feelings of power and energy connected with positive expectations. Most of these changes proved not only in individual lessons, but also from the point of view of the whole programme evaluation. This paper has been written within a project OP VK CZ.1.07/2.4.00/17.0037 „Development of Pedagogical and Research Activities within the Department of Social Sciences in Sport at the FSpS MU“.

Klíčová slova: úzkost a úzkostnost, osoby s tělesným postižením, sport osob s tělesným postižením, Halliwickův koncept plavecké výuky.

Key words: Subjective Experience and Personality States, Anxiety, Trepidation, People with Physical Disability, Sport for the Physically Disabled, The Halliwick Swimming Concept.

(Přispěvek vznikl v rámci řě̌eni projektu OP VK, ,Rozvoj v oblasti pedagogických a výzkumných aktivit na Katedře společenských věd ve sportu na FSpS MU, CZ1.07/2.4.00/17.0037.)

\section{ÚVOD}

Voda je živel nezměrné krásy, ale také síly. Fascinuje nás snad ve všech svých podobách: před velkými vodopády stojíme v němém úžasu, zasněžená krajina má své nezaměnitelné kouzlo, ve vodní páře je ukrytá obrovská síla a energie. Chováme k ní úctu, nebot' si uvědomujeme, že dokáže být dobrým pomocníkem, ale také silným nepř́ítelem.

V počátcích vývoje je vodní prostředí pro člověka přirozené. V průběhu života se však může náš vztah k vodě značně měnit. Malé dítě dokáže být hrou ve vodě a s vodou zaujato dlouhé hodiny, pro mnohé však může být velmi obtížný již samotný kontakt s vodním prostředím. Vzbuzuje strach, úzkost, nejistotu. Tyto pocity člověka značně limitují a omezují, či prrímo znemožňují jeho pobyt ve vodě. 
Se strachem z vodního prostředí se setkáváme nejen u lidí s nepříjemnou zkušeností, ale také u osob pohybově znevýhodněných. Je třeba si uvědomit, že pohyb patří k základním fenoménům života (Blahutková, Řehulka \& Dvořáková, 2005). Přináší řadu př́ijemných pocitů, sportovně pohybové aktivity pak mohou být zdrojem hrdosti, radosti z překonání vlastních hranic a omezení. Řada autorů řadí k nejvhodnějším pohybovým aktivitám osob s postižením právě plavání a vodní aktivity vůbec. Podle Campion (2001) jsou cvičení ve vodě zábavná, radostná, přispívají k duševní pohodě. Jsou šetrná k opěrné soustavě, eliminují především nadměrné zatěžování kloubů, zároveň však přispívají k rovnoměrnému rozvoji svalstva včetně hlubších svalových struktur. Hoch a kol. (1963) zdůrazňují mimo jiné také kladný vliv plavání na rozvoj dýchání a dýchacího ústrojí. Pro osoby s tělesným postižením může samostatný pohyb představovat nepřekonatelný problém. Specifika vodního prostředí však eliminují řadu vlivů limitujících pohyb na souši, a nabízí tak značnou svobodu pohybu.

Vzhledem k pozitivnímu vlivu pohybu ve vodním prostředí a jeho rehabilitační funkci je proto vhodné negativní stavy ovládnout, získat při pohybu ve vodě jistotu a v plavání nalézt vítanou volnočasovou aktivitu.

Strach a úzkost jsou velmi nesnadno odlišitelné emoce. Strach se projevuje nepř́ijemnými pocity, vnitřní nejistotou a neklidem zahrnujícím také pocit ohrožení, a to ve vztahu ke konkrétnímu objektu. Úzkost se ve svých projevech téměř shoduje se strachem, avšak obtížně hledáme prŕíčinu těchto pocitů. Velmi zjednodušeně ji tedy můžeme vymezit jako bezpředmětný strach - prožitky strachu z neznámého nebo jen velmi obecně určeného objektu. Vzhledem k benefitům, které mnozí autoři vodním aktivitám přisuzují (srov. Pacholík \& Trávníková, 2013), je žádoucí takové stavy včas rozpoznat a účinně odstraňovat.

Podstatnou je proto psychická adaptace na vodní prostředí. Rotar (2013) uvádí následující ukazatele neúspěšné či nedostatečné adaptace:

- pevné držení a stisk asistenta při poskytování podpory;

- křečovitě zavřené oči;

- snaha držet ramena nad vodou; 
- zadržování dechu;

- napětí krčních svalů projevující se rozšířením krku;

- snaha držet obličej nad vodou;

- nepříjemné pocity při ponoření uší, a to i v případě, že je obličej nad vodou (napřr. v lehu na zádech).

Všechny tyto projevy je nezbytné eliminovat v počáteční fázi výuky, nebot' nejistota a obavy komplikují postup a pokroky plavce.

Halliwickův koncept plavecké výuky představuje metodiku práce s plavcem, jejímž cílem je dosažení maximální samostatnosti plavce, jeho př́jemných prožitků při pobytu a pohybu ve vodě. Cílem tedy není dokonalost plaveckých pohybů a maximální rychlost plavce, ale radostný pobyt plavce ve vodě s maximální možnou mírou samostatnosti. Tím se odlišuje od obvyklých metodických řad výuky plavání.

Jde o otevřený systém, který se ,vyvijí tak, jak instruktoři rozvíjeji vlastni schopnosti a děli se o ně s dalšími instruktory" (AST, 1994). Ve svých počátcích se metoda zaměřovala především na osoby s různými druhy postižení. Dnes je s úspěchem využívána u všech plavců, kteří vyžadují specifický př́stup. Můžeme ji tedy aplikovat jak u osob s postižením, tak pro překonávání strachu a úzkostných pocitů z vodního prostředí. Své využití nachází také v oblasti prvotního seznámení s vodou i v práci se staršími osobami, které při pobytu ve vodě vyžadují nepřetržitou asistenci. „Prostřednictvím her a aktivit ve vodě odpovidajícím věku a schopnostem konkrétniho plavce ziskává plavec informace o vlastnostech a chováni vody a uči se kontrolovat pohyby vlastního těla “ (HAST, 2011, str. 18).

Základním vodítkem metodiky je Desetibodový program. Udává stěžejní oblasti práce s plavcem, zároveň také pomáhá při hodnocení pokroků plavce. Představuje jakousi logickou kostru průběhu plavecké výuky. Jde o následující kroky (Greswell \& Kelsey, 2006):

1. Psychická adaptace.

2. Uvolnění a osamostatnění se.

3. Transverzální rotace. 
4. Sagitální rotace.

5. Longitudiální rotace.

6. Kombinované rotace.

7. Vztlak - důvěra $\mathrm{v}$ podporu vody.

8. Rovnovážná poloha.

9. Turbulence.

10. Základní plavecké pohyby.

\section{Z hlediska efektivity je třeba akceptovat základní principy kon- ceptu.}

One to one. Princip ,jeden na jednoho“ naznačuje základní organizaci výuky. Samotná lekce probíhá ve skupině, avšak skupinu tvoří dvojice plavec - asistent. Tím je zajištěna dopomoc a prríp. záchrana plavce, jeho podpora při pobytu ve vodě, ale také práce s motivací, zvyšování jistoty a pocitu bezpečí plavce atd.

Face to face. Princip ,tváří v tváŕc hraje roli především při odbourávání strachu plavce a posilování jeho pocitu bezpečí. Asistent pomocí vizuálního kontaktu může plavce podporovat a motivovat, dává mu jistotu neustálé kontroly a odpoutává jeho pohled od vodní plochy, která může působit jako zdroj obav.

Práce bez nadnášecích pomůcek. Halliwickův koncept nevyužívá nadnášecí pomůcky jako hlavní způsob podpory, ale spíše jako doplňkové pomůcky. Stěžejní úlohu v podpoře plavce hraje školený asistent. Podle Halliwick Association of Swimming Therapy (2004) tyto pomůcky především nevhodně omezují rotace plavcova těla (které jsou účelně využívány pro nácvik jejich zvládání), nejsou tak adaptabilní jako asistent, drží plavcův obličej daleko od vody a brzdí tak nácvik zvládání této dovednosti a jejich použití odlišuje ve skupině plavce od neplavců. Dodejme, že rozlišení plavec - neplavec používáme $\mathrm{v}$ tomto textu čistě účelově. V Halliwickově konceptu je doporučováno, aby všichni účastníci lekce byli označováni jako plavci, a to bez ohledu na úroveň jejich plaveckých dovedností. Působíme tak na motivaci a zabraňujeme nežádoucímu poukazování na slabší plavce ve skupině. 
Svým charakterem a zaměřením se nám Halliwickův koncept jeví jako vhodná cesta $\mathrm{k}$ odstranění strachu a úzkostných prožitků plavců.

\section{VÝZKUM VLIVU HALLIWICKOVA KONCEPTU NA PROŽITKY STRACHU A ÚZKOSTI - PŘíPADOVÁ STUDIE}

\section{CÍl}

Autor článku provedl v rámci své dizertační práce (Pacholík, 2012) výzkumné šetření s cílem ověřit vliv programu plavecké výuky s prvky Halliwickova konceptu na subjektivní prožitky a stavy osobnosti a na míru úzkostnosti osob s tělesným postižením.

V rámci dizertační práce autora jsme podrobili výzkumnému šetření celkem osm dospělých plavců $\mathrm{s}$ tělesným postižením a převládajícím negativním vztahem k vodnímu prostředí.

\section{VÝZKUMNÝ SOUBOR}

Výzkumný soubor tvořilo osm osob $\mathrm{s}$ tělesným postižením, př́íp. s postižením kombinovaným, z toho 3 ženy a 5 mužù. Dvě osoby byly uživateli berlí, šest osob bylo uživateli vozíku. Věk testovaných osob se pohyboval v rozmezí $21-42$ let. $Z$ důvodu vysokého absentismu na lekcích jsme však vyhodnotili data pouze 3 probandů, kteří absolvovali výuku v plném rozsahu. Podrobné anamnézy uvádíme ve zmíněné práci (Pacholík, 2012).

\section{METODY VÝZKUMU}

Program plavecké výuky podle Halliwickova konceptu proběhl v 10 lekcích s frekvencí jedné lekce týdně, délka lekce se pohybovala mezi 30 a 50 minutami.

Mezi použité metody výzkumu jsme zařadili Osobnostni anketu pro plavce, jejímž cílem bylo získat základní údaje o plavcích (tzv. „tvrdá data") a dále zkušenosti s plaváním a jejich vztah $\mathrm{k}$ vodě. Pro detailní osobnostní charakteristiku jsme použili Dotazník SPARO a pro analýzu 
aktuálních subjektivních prožitků a stavů před lekcí a po jejím skončení Dotazník SUPSO. Tyto metody jsme doplnili údaji získanými zúčastněným pozorováním a nestrukturovaným interview.

\section{VYBRANÉ VÝSLEDKY}

Pro vyhodnocení změn psychických stavů a prožitků ve vztahu k vodnímu prostředí jsou stěžejní data Dotazníku SUPSO. Jejich podrobnou interpretaci uvádíme v dizertační práci autora (Pacholík, 2012), zde se vzhledem $\mathrm{k}$ rozsahu textu omezíme na ukázku vyhodnocení průběžných změn psychických prožitků a stavů klienta K2 během celého intervenčního programu plavecké výuky.

Na obrázku 1 uvádíme průběh změn těch škál, které stojí v centru zájmu naší studie. Při globálním hodnocení škál ,KD - Psychický komfort vs. psychický dyskomfort', škála ,U - Úzkostné očekávání', škála ,P - Psychická pohoda' a škála ,D - Psychická deprese, pocity vyčerpání můžeme konstatovat pozitivní změny. Ve všech sledovaných kategoriích se podařilo během programu plavecké výuky navodit žádoucí změny. Trend postupného tlumení negativních a posilování pozitivních prožitků je patrný nejen $\mathrm{z}$ hodnot klouzavého průměru, ale také u většiny realizovaných lekcí.

V jistém ohledu se tomuto trendu vymyká pátá lekce z hlediska psychické deprese a pocitů vyčerpání, kde došlo ke značnému nárůstu hodnot. Tyto změny jsou patrné nejen z pohledu konkrétní lekce, ale také ve srovnání s lekcemi ostatními a výrazně se tedy vymyká obecnému trendu postupné tlumení pocitů vyčerpání. Určitým specifikem je také desátá lekce. Zde jsme zaznamenali nečekaný posun těžiště psychických stavů do pásma výrazného psychického komfortu (tedy pozitivních prožitků), avšak hodnoty psychické pohody tomu př́liš nenasvědčují. Došlo sice k žádoucímu posunu, ten však není zdaleka tak výrazný, jako u posunu těžiště. Nutno dodat, že již před začátkem lekce můžeme pozorovat odlišné charakteristiky oproti lekcím předchozím. Tato zjištění jsou v souladu s údaji získanými rozhovorem, ve kterém klient uvádí opětovné obavy a strach a působí velmi unaveně a apaticky. $\mathrm{V}$ dalších lekcích 
se však již tento stav neobjevil. Také v souvislosti s desátou lekcí klient uvádí zvýraznění negativních pocitů, a to v souvislosti se zaměřením lekce na soutěživé hry, tedy výkonovou situaci.

$\mathrm{Z}$ důkladné analýzy osobnostních rysů klienta i z průběžného pozorování je patrná obecná úzkost a tendence k neustálému kontrolování svého chování a ujišt'ování se o správnosti provedení pohybových prvků a úkolů (obr. 1). Výkonové situace desáté lekce tak klienta přiváděly do neprŕíjemných situací se zvýšeným rizikem selhání.
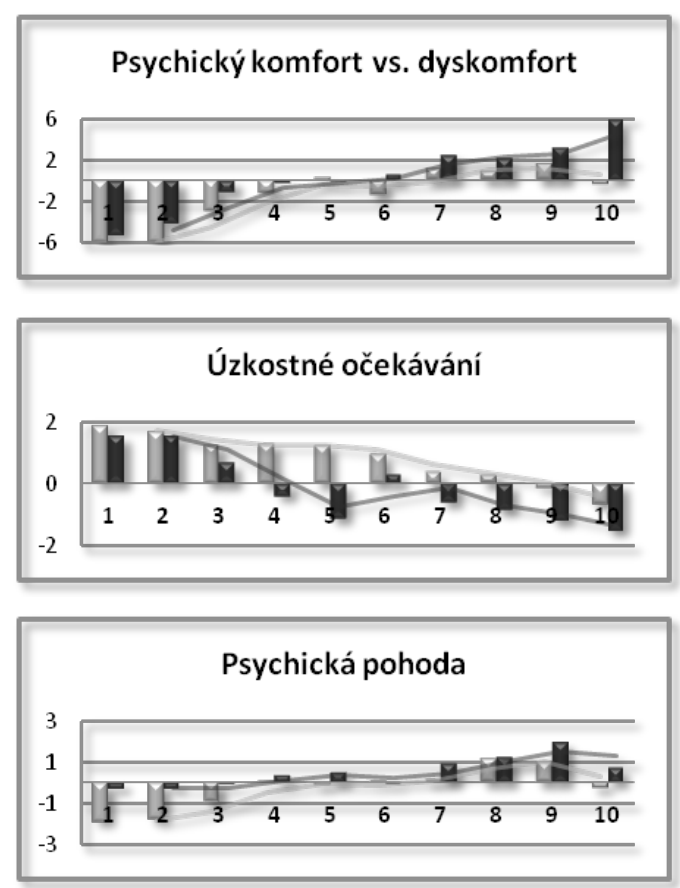


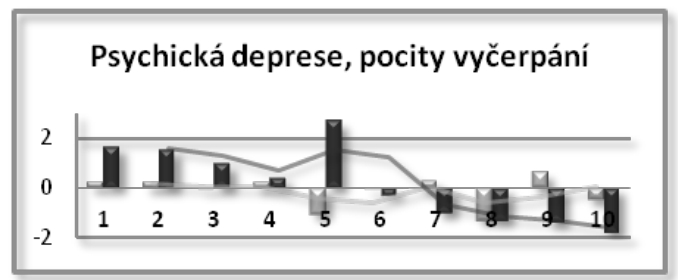

Obr. 1: Dotazník SUPSO - Průběžné výsledky za měření v jednotlivých lekcich, $K 2$

\section{Legenda:}

- Před lekci $\square$ Po lekci

- Kl. prüměr před lekci $-K l$. průměr po lekci

\section{DISKUZE A ZÁVĚR}

Většina klientů v našem výzkumu vykazovala před zahájením lekcí negativní ladění, po skončení lekcí bylo možné pozorovat zmírnění úzkostných pocitů a stavu sklíčenosti. Do určité míry je možné tyto výsledky očekávat bez ohledu na náplň samotné lekce a její působení na psychiku plavců. Především v počátečních lekcích sami klienti zmiňovali pocit úlevy, když lekce skončila a oni mohli z bazénu, nebot' pominuly příčiny jejich strachu a dalších negativních prožitků. Svou roli také mohla hrát hrdost klientů, vědomí, že obávaný pobyt v bazénu zvládli a dokázali se tak poprat $\mathrm{s}$ intenzivními nepř́ijemnými pocity. Proto jsme se při interpretaci výsledků jen okrajově zaměřili na jednotlivé lekce a změny v rámci nich. Svůj zájem jsme orientovali spíše na tendenční charakter těchto změn $v$ průběhu celého programu plavecké výuky, a to zvlášt' v oblasti prožitků a stavů před lekcí a zvlášt’ po jejím skončení. Zajímalo nás tedy, jestli se intenzita negativních stavů pocit’ovaných před jednotlivými lekcemi bude snižovat a míra pozitivních prožitků a stavů zvyšovat. Totéž jsme sledovali u výsledků získaných po skončení plaveckých lekcí. 
Z výsledků získaných v první části výzkumu vyplývá, že po skončení plaveckých lekcích sice došlo ke zmírnění většiny negativních stavů, především úzkosti, avšak za současného zvýraznění pocitu psychické únavy až vyčerpání, apatie a celkového útlumu. Tomuto fenoménu nelze přikládat velkou důležitost. Překonávání anxiózních pocitů, strachu, sklíčenosti a nejistoty představuje značné psychické vypětí. Je tedy logické, že po pominutí „ohrožujícího“ podnětu se dostaví únava a vyčerpání. Podstatné pro náš výzkum však je, že se tyto projevy v průběhu výzkumu tlumí a v posledních lekcích už jsou minimální, příp. se nevyskytují vůbec.

Závěrem je třeba upozornit na fakt, že vzhledem k počtu probandů není možné výsledky zobecnit. Naší snahou proto je rozšiŕit výzkum na větší počet plavců a potvrdit tak výsledky, které naznačuje naše výzkumné šetření.

\section{LITERATURA}

AST. (1994). Swimming for people with disabilities. London: A \& C Black.

Blahutková, M., Řehulka, E., \& Dvořáková, Š. (2005). Pohyb a duševní zdraví. Brno: Paido.

Campion, M. R. (2001). Helath Promotion. V M. R. Campion, Hydrotherapy: Principles and practice (str. 336). Oxford: Butterworth-Heinemann.

Greswell, A., \& Kelsey, B. (Režiséři). (2006). Activities on the Ten Point Programme [Film]. Oxford.

Halliwick Association of Swimming Therapy. (2004). The Halliwick Concept: Foundation Course Handbook $\left(14^{\text {th }}\right.$ Edition - With supplement. vyd.). London: Halliwick AST.

HAST. (2011). Information for Halliwick Course Organisers. Získáno 15. listopad 2011, z HalliwickAST: Halliwick Association of Swimming Therapy in the UK: http://www.halliwick.org.uk/wp-content/ uploads/2010/12/Organisation-Pack-for-Halliwick-FoundationCourses-with-cover-2011.pdf. 
Hoch, M., Bělohlávek, J., Hofer, Z., Juřina, K., Kilár, L., Komadel, L., ... Záboj, O. (1963). Základy sportovního plavání. Praha: Sportovní a turistické nakladatelství.

Pacholík, V. (2012). Výzkum vlivu programu plavecké výuky s prvky Halliwickova konceptu na změny subjektivních psychických stgavů osob s tělesným postižením. Disertační práce. Brno: Masarykova univerzita, Fakulta sportovních studií.

Rotar, N. (20. května 2013). Učenje plavanja po konceptu Halliwick. Brno.

\section{KONTAKT:}

Mgr. Viktor Pacholík, Ph.D., pacholik@fsps.muni.cz 